\title{
A socio-psychological approach for understanding and managing bycatch in small-scale fisheries
}

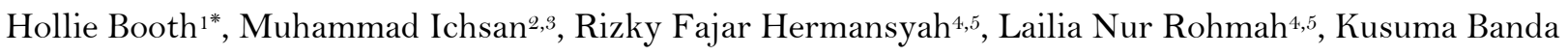
Naira $^{6}$, Luky Adrianto ${ }^{4}$, EJ Milner-Gulland ${ }^{1}$

*Corresponding author: hollie.booth@zoo.ox.ac.uk.

1. The Interdisciplinary Centre for Conservation Science (ICCS), Department of Zoology, University of Oxford, 11a Mansfield Rd, Oxford OX1 3SZ, United Kingdom

2. Coral Triangle Initiative, Manado, North Sulawesi

3. ZSL EDGE of Existence

4. Bogor Agricultural University, Faculty of Fisheries and Marine Sciences

5. Directorate-General of Surveillance and Control of Marine and Fishery Resources, Ministry of Marine Affairs and Fisheries of Indonesia

6. Aceh Jaya Regency Extension Office, Ministry of Marine Affairs and Fisheries of Indonesia

\section{Abstract}

Fisheries bycatch is the greatest threat to migratory, long-lived marine animals. Addressing bycatch ultimately requires changing fisher behaviour, yet social and behavioural sciences are rarely applied to bycatch mitigation, with an absence of theory-informed behaviour change interventions. Moreover, mitigating bycatch is particularly challenging in small-scale mixed-species fisheries, where perceptions of target and non-target vary widely, and all catches have economic or subsistence value. Such fisheries are ubiquitous throughout the world's oceans, and bycatch mitigation in these contexts necessitates a peoplecentered approach. We seek to address this gap, drawing on well-established theories from behavioural and social sciences. We first typify bycatch as a spectrum rather than a clearly delineated component of catch, where the position of a species on this spectrum depends on fishers' beliefs regarding the outcomes of bycatch-relevant behaviour. We then outline an approach to diagnose fishers' underlying beliefs about bycatch, using the Theory of Planned Behaviour (TPB): a widely-applied and empirically-tested theory for predicting and changing behaviour. Finally, we illustrate the approach using an empirical case study, 
exploring fishers' beliefs regarding bycatch-relevant behaviour for three endangered elasmobranch species in a small-scale gill net fishery in Indonesia. In doing so show how the TPB can help to understand fishers' underlying beliefs regarding bycatch, and facilitators/inhibitors of bycatch mitigation, to inform behaviour change interventions. We emphasize the need to understand human dimensions of bycatch, especially in SSFs, where technical fixes alone will be insufficient to change behaviour. Rather, interdisciplinary approaches are needed to align fishers' needs with conservation objectives. Our bycatch spectrum and the TPB could be widely applied for disentangling drivers of bycatch in other SSFs and designing interventions which support more effective and socially-just marine conservation.

Key words: behaviour change, conservation, elasmobranchs, incentives, social norms, theory of planned behaviour

\section{Introduction}

Marine megafauna, such as sharks, turtles and cetaceans, are amongst the world's most threatened species (IUCN, 2021). The main threat is overfishing, sometimes via targeted fisheries, but most ubiquitously via incidental mortality (i.e. bycatch) (Davies et al., 2009; Lewison et al., 2004). This is common and particularly problematic in small-scale multi-species fisheries, where unselective gears are used to opportunistically catch a variety of fish (Shester \& Micheli, 2011). In general, but in these types of fisheries in particular, bycatch is poorly defined, because perceptions of target and non-target vary (Davies et al., 2009). In practice, bycatch occurs on a spectrum (Figure 1), from undesirable incidental catch, which can be costly to fishers, to valuable retained secondary catch, which fishers may secondarily target. When seeking to manage bycatch in a particular context, it is important to diagnose where along this spectrum a given species falls, to design interventions that can effectively change bycatch-relevant behaviour. For example, if bycatch is undesirable, a low-cost technical fix may be feasible, however if bycatch mitigation has opportunity costs, incentives or compensation may be required to promote uptake (Hall, 1996; Matwal et al., 2014; Wosnick et al., 2020) (Figure 1). 


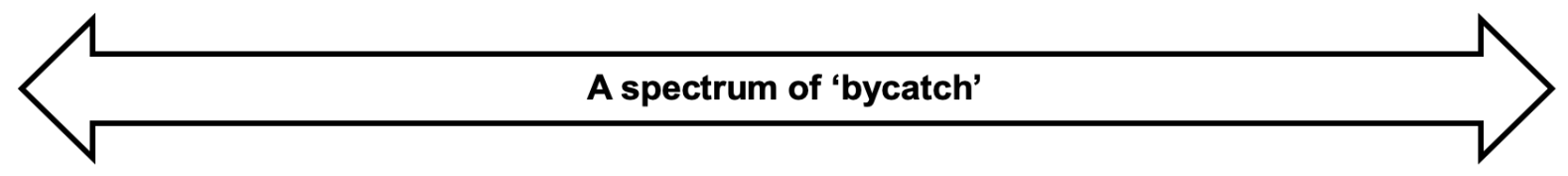

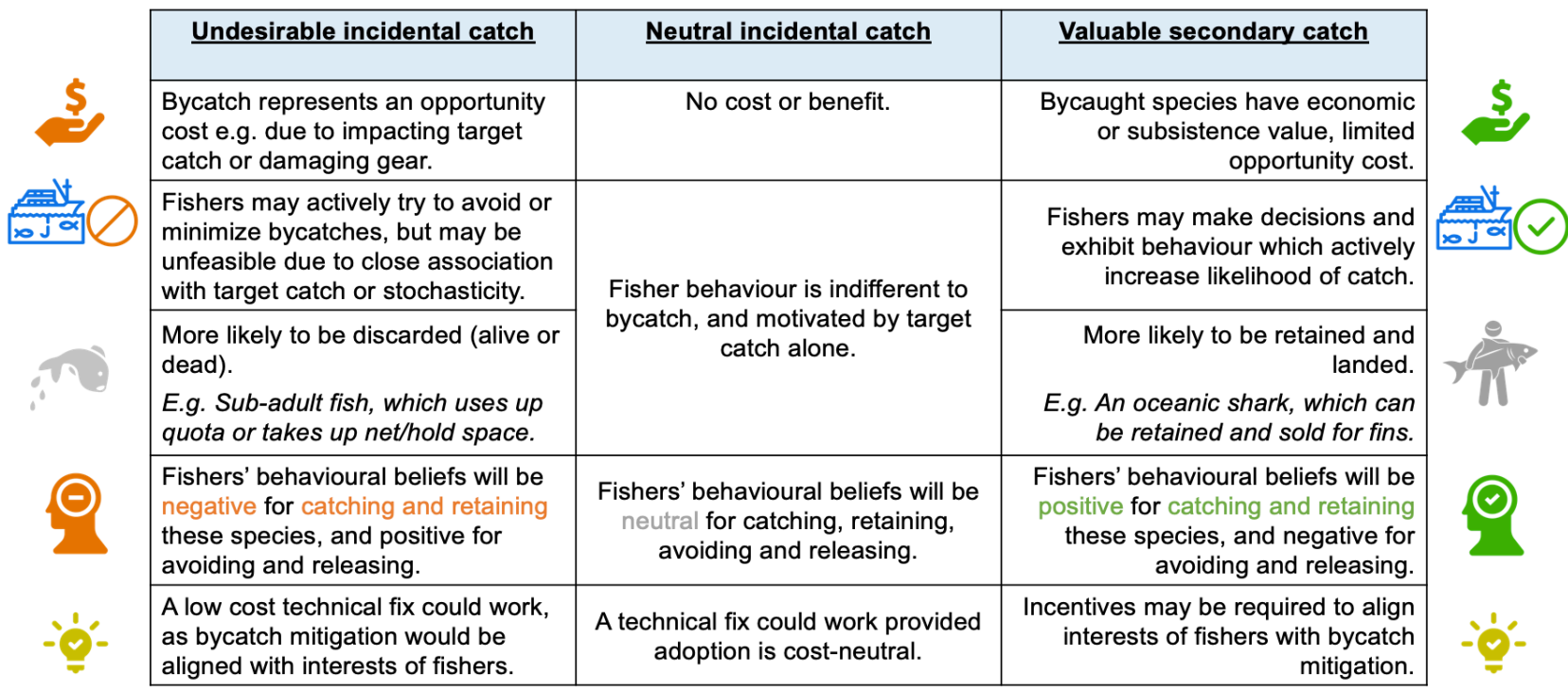

Figure 1. A spectrum of bycatch, from undesirable incidental catch which has opportunity costs to useful secondary catch, which may have economic or subsistence value. Fishers' underlying beliefs, and appropriate interventions to change fisher behaviour, will be different at different places along the spectrum.

At its core, diagnosing and managing bycatch requires understanding and changing fisher behaviour, yet the use of behavioural sciences to inform marine governance and policy remains limited (Andrews et al., 2021; Campbell \& Cornwell, 2008). A people-centred approach to bycatch mitigation in particularly important in SSFs, where almost all catches contribute to fishers' overall livelihood strategies, such that bycatch typically falls in the 'valuable secondary catch' category (Figure 1). This issue is ubiquitous throughout coastal areas - particularly in the Global South, where hotspots of marine biodiversity and dependency on marine resources overlap - and represents a cross-disciplinary challenge for biodiversity conservation, food security and livelihoods (Golden et al., 2016; Selig et al., 2014, 2018).

To contribute towards tackling this challenge, we outline how methods from social psychology specifically, the Theory of Planned Behaviour (TPB) - can be applied to understanding and managing bycatch (Ajzen, 1991). We then illustrate the TPB's utility for eliciting information regarding fishers' beliefs about bycatch-relevant behaviour, with empirical data in a case study SSF: Lhok Rigaih in Aceh Province, Indonesia. This is an important case study because: 1) Indonesia is the world's largest shark fishing nation, where $99 \%$ of the fleet is small-scale, and is thus a global priority for reconciling trade-offs between biodiversity conservation, food security and livelihoods (Dent \& Clarke, 2014; Dulvy et al., 2017; Halpern et al., 2008; Selig et al., 2018). 2) Lhok Rigaih is a multi-species multi-gear SSFs, in which Critically 
Endangered species - such as hammerhead sharks (Sphyrna spp.) and wedgefish (Rhynchobatus spp.) - are regularly caught as part of fishers overall livelihood strategies (Simeon et al., 2020). This is representative of other SSF s in Indonesia, in the Global South more generally (Booth, Chaya, et al., 202 1; Gupta et al., 2020; Haque et al., 2021). Using this case study, we show how the results can be used to inform intervention strategies to change bycatch-relevant behaviours. Finally, we outline broader implications and ways forward for future applications, to design more effective and socially-just interventions for bycatch mitigation.

\section{A socio-psychological approach to bycatch}

Bycatch mitigation ultimately seeks to change human behaviour, by altering fishers' strategic and tactical decisions to, for example, avoid hotspots, adopt bycatch-reducing technologies (BRTs), or release threatened species (Campbell \& Cornwell, 2008; Hall, 1996). Despite this, behavioural and social sciences are rarely applied to understanding and managing bycatch (Andrews et al., 202 1; Campbell \& Cornwell, 2008). To date, technologies and practices for mitigating bycatch (i.e. 'technical fixes') are relatively well documented (e.g. BMIS, 2021), but less is known about how to encourage their adoption.

Interventions to change behaviour may be more effective if grounded in appropriate theory (Davis et al., 2015). There are many theories of behaviour and behaviour change which can be applied to solving environmental problems (Davis et al., 2015; Stern, 2018). We focus here on the TPB (Ajzen, 1991) since it is one of the most widely-applied and empirically-tested theories of behaviour, including for predicting and informing pro-environmental behaviour change (e.g., recycling), but with limited application to marine conservation and fisheries management (Andrews et al., 2021; Davis et al., 2015; Nigbur et al., 2010; St John et al., 2010; Tonglet et al., 2004).

According to the TPB a person's behaviour is determined primarily by intention (i.e., readiness to perform a behaviour). Intention to perform a behaviour is driven by three factors: 1) attitude towards a behaviour, 2) subjective norm and 3) perceived behavioural control (Ajzen, 1991). In turn, these factors are influenced by an individual's beliefs about a behaviour: 1) behavioural beliefs, 2) normative beliefs and 3) control beliefs, respectively (Ajzen, 1991) (Figure 2). Attitudes are based on the outcome expectations of performing a behaviour (e.g., "I think it would be good if I catch a shark"), which are in turn influenced by individual's 
positive or negative evaluation of the consequences of the behaviour (e.g., "catching a shark will provide food

and income"). Subjective norms refer to perceptions of social pressure to behave in a certain way and can be divided into two types; descriptive - perceptions of peers' behaviour, and injunctive - perceptions of whether peers approve or disprove of a behaviour (e.g., "People who are important to me would want me to catch a shark”). Social norms are influenced by normative beliefs about important peers approving or disapproving of a behaviour, and an individual's motivation to comply with their peers' views. Perceived behavioural feel it is within my control whether or not I catch a shark”). PBC is influenced by control beliefs about the likelihood that facilitators (e.g., the season, available technology) or inhibitors (e.g., bad weather) might occur that help or hinder the likelihood of performing a behavior. As well as driving behavioural intentions PBC also directly influences behaviour (Figure 2) (Ajzen, 1991). In general, the more positive a person's behavioural, normative, and control beliefs, the greater their behavioural intention, and the higher the likelihood that they perform a behaviour, and previous studies have shown that they reliably predict other pro/anti-environmental and -social behaviours, such as recycling, smoking and healthy eating (Davis et al., 2015; Nigbur et al., 2010; Tonglet et al., 2004). Moreover, identifying and changing salient beliefs can influence intended and actual behaviours.

A

What do I think about this behaviour?

Individual outcome evaluation

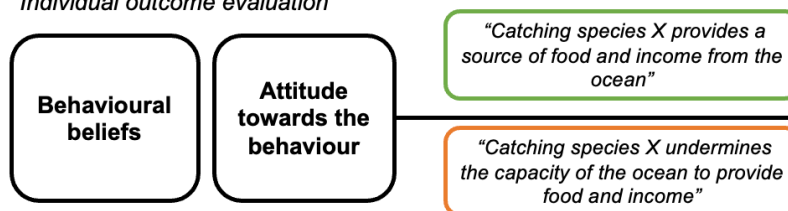

What do other people who are important to me think about this behaviour? Social context and culture

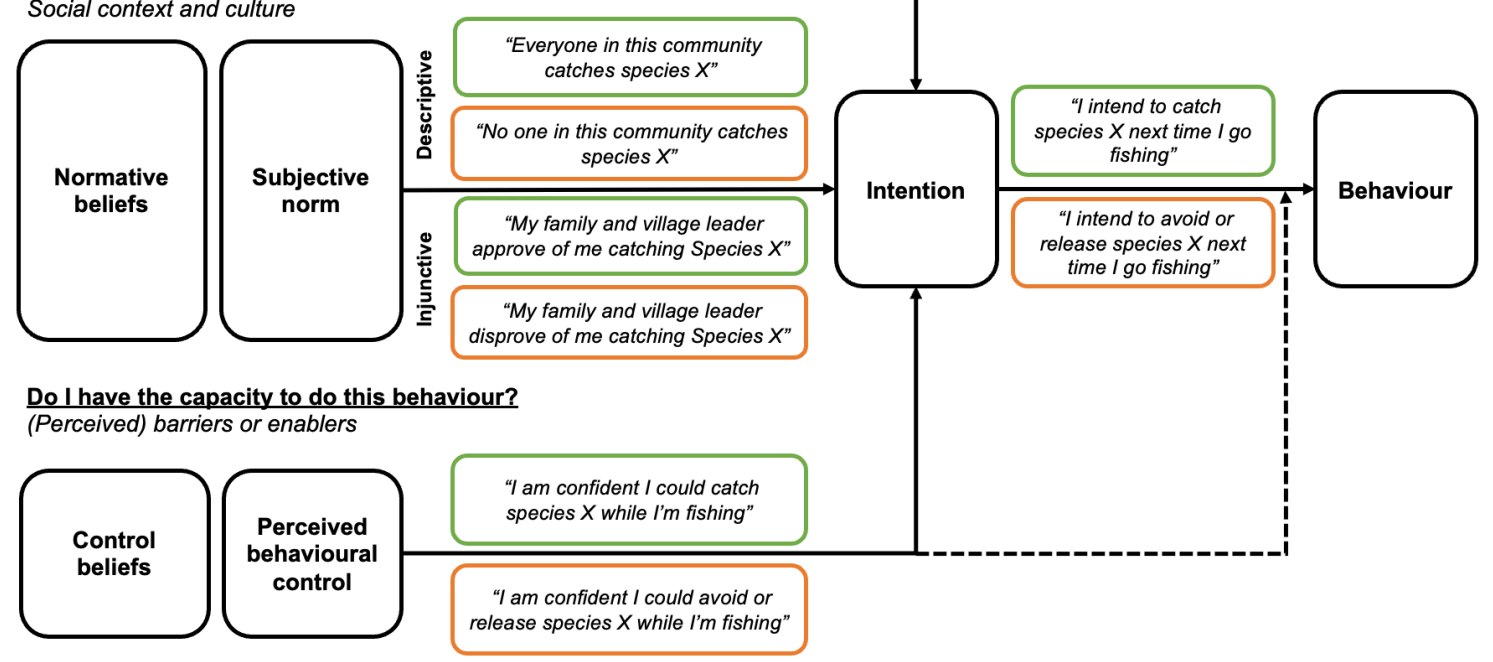

B 


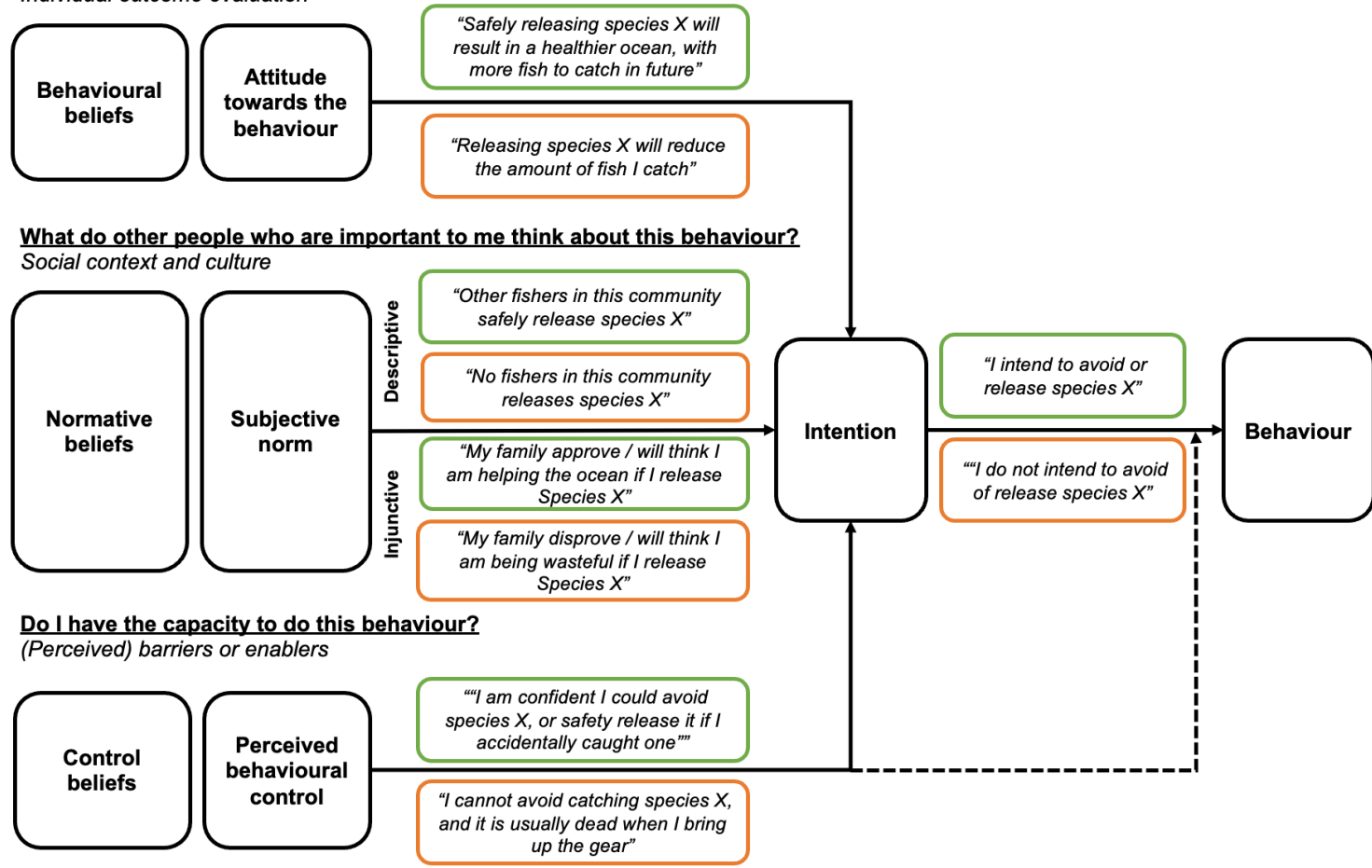

Figure 2. The theory of planned behaviour, with example beliefs relevant to bycatch. Panel A relates to catching species X while Panel B relates to avoiding or releasing species X. Green boxes represent positive beliefs towards the behaviour and orange boxes represent negative beliefs towards the behaviour. (adapted from St. John et al. 2010).

TPB is particularly appropriate for fisher behaviour, since it acknowledges that behaviour is multi-faceted, multi-levelled and multi-scaled (Andrews et al., 202 1). That is, TPB allows for different types of outcome expectations with different levels of influence (e.g., behavioural beliefs, which depend on perceived external rewards at the individual-level; normative beliefs, which depend on social pressure at the societal-level; control beliefs relating to environment/context). Unpacking these influences on fisher behaviour is important, since different beliefs can act synergistically or antagonistically, and may align or be in conflict with conservation objectives. For example, outcome expectations which are extrinsically rewarding (e.g. food, income) can crowd in or crowd out those which are intrinsically rewarding (Cinner et al., 202 1; Grillos et al., 2019). Similarly, different scales of influence can interact, such as conflicts and synergies between individual beliefs and social norms, or between formal laws and local customs (Bicchieri, 2017; Booth et al., 2020; Oyanedel et al., 2020). Bycatch mitigation in SSFs is also a challenge for equity and environmental justice. Coastal communities often experience the greatest opportunity costs of marine conservation, with a we need for a deeper understanding of the values and importance of marine megafauna from the perspectives of small-scale fishers (Balmford \& Whitten, 2003; Booth, Squires, et al., 2021; Stevenson et al., 2013). TPB can help to meet this need by building a deeper understanding about the advantages/disadvantages of 
bycatch and bycatch mitigation, and socio-economic barriers and facilitators thereof. Therefore, applying the TPB to bycatch can help to unpack fishers' salient beliefs about bycatch, and underlying socio-economic drivers. For example, if attitudes and norms towards catching threatened species are negative, but perceived behavioural control towards avoiding them is also negative, interventions which improve behavioural control (such as cost-effective BRTs) could be appropriate. Conversely, if attitudes and norms towards catching threatened species are positive, underlying socio-economic motivations may hinder uptake. In these situations, economic or social incentives may be required (Nyborg et al., 2016; Sykes et al., 2018; Wosnick et al., 2020). This information can help to 'diagnose' the typology of bycatch (Figure 1) for a given species and context, and inform the design of management interventions to target salient beliefs and change fisher behaviour.

\section{Case study: using the TPB to understand bycatch-relevant behaviour in an SSF}

\section{in Indonesia}

\section{Case Study background and methods}

We illustrate application of the TPB for eliciting fishers' salient beliefs regarding bycatch-relevent behaviours in a coastal gill net fishery in Lhok Rigaih, Aceh Province, Indonesia. This is a pertinent case study for several reasons. Firstly, Indonesia is a global priority for aligning SSF management, marine conservation and human well-being (Golden et al., 2016; Selig et al., 2014, 2018). Secondly, the fishery context is representative of coastal SSFs in the tropics in terms of gears, habitat types and bycatch-affected species, therefore the methods and findings should be broadly applicable to other SSF s around the world (Gupta et al., 2020; Haque et al., 2021; Harry et al., 2011). Finally, the socio-cultural context in Aceh Province represents an interesting case for testing a socio-psychological approach, as it is home to a customary fisheries management institution called the Panglima Laot, which is responsible for maintaining security at sea and managing coastal resources (Quimby, 2015; Wilson \& Linkie, 2012). It therefore represents a location where expectations regarding economic outcomes and social norms interact within the realm of fisheries management and conservation.

Within this site we conducted a belief elicitation study structured around the TPB which aimed to answer the following questions: 
1. What are fishers' salient beliefs regarding three by-catch relevant behaviours: a) (by)catching and retaining, b) not catching/avoiding, and c) releasing endangered species?

2. Based on these beliefs, where does fisher behaviour sit along the spectrum of bycatch (Figure 1)?

3. What are the implications for designing of behaviour change interventions for bycatch mitigation?

For each by-catch relevant behaviour we conducted a comparative case study of three endangered elasmobranch species: hammerhead sharks (Sphyrna spp.), wedgefish (Rhynchobatus spp.) and whale sharks (Rhincodon typus), which represent conservation priorities, and contrasting case-types in terms of their ecology and socio-economic characteristics.

\section{Site description}

Aceh Jaya regency is on the south coast of Aceh Province, Indonesia. It is home to important marine habitats, with extensive mangroves, turtle nesting beaches, and shallow coastal waters with muddy substrate and coral reefs which provides nursery grounds for a range of endangered species (DKP Aceh, 2018). Much of Aceh Jaya's population adopt mixed subsistence livelihoods such that the coastal waters of Aceh Jaya also represent an important marine resource, characterised by small-scale multi-gear mixedspecies fisheries which support food security and livelihoods (Yulianto et al., 2018).

In Aceh under the Panglima Laot, coastal management is primarily conducted at the 'Lhok' level. Lhok essentially translates to bay, and is a spatial area encompassing a portion of the coast and associated marine habitat, which is the smallest unit of customary management in Aceh according to customary law (Qanun Aceh Nomor 9 Tahun 2008 Tentang Pembinaan Adat Dan Adat Istiadat, 2008). There are 8 registered Lhoks in Aceh Jaya, and Lhok Rigaih is home to the largest harbour and landing site in the regency. It serves six villages across two districts and approximately 200 full- and part-time fishers, while also being representative of the other Lhoks in Aceh Jaya in terms of fishery characteristics (i.e. gears uses, species caught and habitat) (Yulianto et al., 2018). There are three main gear types used in Lhok Rigaih - gill nets (jaring), longlines (rawai) and handlines (pancing), with available data indicating that bottom-set gill nets (jaring tancap) are by far the highest-risk gear in terms of bycatch of endangered species, accounting for roughly $80 \%$ of total hammerhead sharks and wedgefish bycatch (Simeon et al., 2020). Landed hammerheads are typically juveniles, and therefore represent limited economic value per individual, but are caught frequently and consumed locally (Simeon et al., 2020). In contrast, large wedgefish have high value in the 
international fin trade (Hau et al., 2018). In contrast again, while whale sharks are anecdotally encountered by fishers, and can become entangled in gill nets, they are rarely caught and landed in Lhok Rigaih.

\section{Study design and data collection}

When applying the TPB, belief elicitation studies are conducted to understand salient beliefs among a target population, which can inform the design of behaviour change interventions by identifying which beliefs should be targeted (Ajzen, 1991, 2011). We used in-depth semi-structured interviews as our primary data collection method, to elicit fishers' salient beliefs, and gather additional qualitative and quantitative data on the socio-ecological system of the fishery (fishing practices, subjective well-being, social relations, and institutions) and individual demographic variables of the fishers (e.g., age, income, experience) (S1). We structured the interview questions following guidance from Ajzen 2013 (Ajzen, 2013b, 2013a). Specifically, we asked questions regarding beliefs about the likely consequences of each by-catch relevant behaviour (behavioural beliefs), normative expectations of others regarding the behaviours (normative beliefs), and the presence of factors that may facilitate or impede performance of the behaviours (control beliefs), where the behaviours examined were catching species $\mathrm{X}$, not catching species $\mathrm{X}$ and releasing species $\mathrm{X}$. For each belief we asked Likert-scale questions on a scale from 1 to 7 , where 1 represented a strongly negative response, 4 represented a neutral response and 7 represented a strongly positive response, and responses were framed as varying degrees of good/bad, true/false or agree/disagree along this 7-point spectrum depending on if the question referred to advantages/disadvantages, approvers/disapprovers, facilitators/barriers (S1). Each Likert-scale question was then followed with a qualitative open-ended question, where fishers were asked to explain their answers and describe the relevant advantages/disadvantages, approvers/disapprovers, facilitators/barriers (S1).

In total we conducted 16 in-depth semi-structured interviews (14 with active jaring tancap fishers and two with active jaring lobster fishers who has previously used jaring tancap), complemented with an FGD with local marine managers, and informal discussions and direct observations at Lhok Rigaih harbour and a local coffee shop. Since this was a descriptive and exploratory study, we conducted opportunistic, snowball sampling, with no a-prior assumptions regarding sample sizes, and continued collecting data until saturation (Cohen \& Crabtree, 2006; Newing et al., 2010). At the time of the study, eight jaring tancap boats were operating in Lhok Rigaih, which can employ up to 24 fishers, with each vessel taking $2-3$ crew. As such, we 
estimate our sample represented at least $58 \%$ of the active jaring tancap fishers. Our sample focused on vessel captains (10 out of 16) and included the current Panglima Laot of Lhok Rigaih as key informants. The FGD included eight local marine managers from the Aceh Jaya regency Panglima Laot and regency fisheries agency.

Data were collected during February 2021, by the lead author (HB) with assistance from a translator (MI), two trained research assistants (LR and $\mathrm{RH}$ ) and a local enumerator to facilitate introductions to fishers $(\mathrm{KBN})$. This research was conducted under a foreign research permit for the lead author (No. Surat Izin: 407/ E5/E5.4/SIP/2019), with ethical review and approval from the University of Oxford Medical Sciences Interdivisional Research Ethics Committee (MS IDREC) (ref. R66416/RE001).

\section{Analysis}

We conducted simple descriptive and thematic analysis of the results, with graphical figures prepared using RStudio (RStudio Team, 2020).

\section{Case Study Results}

\section{Socio-ecological context}

Gill net fishers in Aceh Jaya are typically middle-aged (30 to 59 years) married men, with primary- or middle-school level formal education and many years of fishing experience (average $=25$ ). Every fisher reported that they target 'ikan apa pun'/'ikan apa saja' (any fish), reflecting the mixed-species nature of the fishery, and that fishing covers their 'kehidupan sehari-hari (daily needs or livelihood). Most fishers reported positive or neutral subjective well-being, and expressed a strong sense of ocean stewardship (e.g., "ada rezeki di laut" (there are gifts from God in the ocean)) and social connectedness (e.g., "di laut semua saudara" (at sea we are all brothers)) (S2).

\section{Catching, avoiding and releasing endangered elasmobranchs: fishers' beliefs, intentions, and behaviour} Beliefs

Fishers reported strong positive behavioural and normative beliefs regarding catching wedgefish and hammerheads (Figure 3), with neutral to negative beliefs regarding avoiding and releasing them (Figure 4). 
In contrast, they held strong negative beliefs regarding catching whale sharks (Figure 3), and positive beliefs regarding avoiding and releasing them (Figure 4).

Positive behavioural beliefs were strongest for catching wedgefish (mean score of 5.9/7 on Likert scale, Figure 3), with all fishers stating financial gain as an advantage e.g. "If it's big it's great, I can get lots of money". Behavioural beliefs for catching hammerheads were also consistently positive, with food more commonly mentioned as an advantage (mean $=5.5 / 7$, e.g., "We can sell it or eat it"). The term "rezeki" (gift from God) was also commonly used to describe these catches (Figure 3). Attitudes were reinforced by normative beliefs, with almost all fishers believing that most people catch wedgefish and hammerheads, and approve of their capture e.g., "They are landed here every day", "People approve... we eat it" (Figure 3). Control beliefs for wedgefish and hammerheads were generally positive but less consistent, with fishers reporting stochasticity as a barrier, e.g., it depends on "luck" and/or "God's will" (Figure 3).

Behavioural beliefs regarding not catching wedgefish and hammerheads were neutral-to-negative, with many stating "tidak apa-apa” (no problem) or "Insh'Allah" (if God wills). Control beliefs for avoidance were generally negative, with fishers stating "they just come to the net" (for wedgefish) or "they are everywhere" (for hammerheads), though some fishers revealed seasonal and spatial elements to bycatch, with catches of hammerhead sharks being particularly high during May to August. Behavioural beliefs regarding releasing wedgefish and hammerheads were also generally negative. Disadvantages included less income (e.g., "it brings more money even though it's not the target') and 'mubazir'. Mubazir literally translates as wasteful, but also has religious connotations, and implies that God will be displeased. However, some fishers reported advantages, e.g., "if it's small and alive ... it can make more fish". Control beliefs regarding releasing wedgefish and hammerheads were heterogenous. For wedgefish, control beliefs were neutral-to-slightly positive, with reports that they are sometimes alive and typically "stronger than hammerheads". For hammerheads, four fishers reported strong positive control beliefs and four reported strong negative control beliefs. Those that reported negatively stated that hammerheads are usually or always dead when the gear is brought up, while those that reported positively conditioned their answer with "if it's small and alive" (Figure 4).

In contrast, all but one fisher $(\mathrm{N}=15)$ consistently reported strong negative beliefs regarding catching whale sharks and strong positive beliefs regarding releasing them, which were backed up by statements 
regarding customary beliefs and norms (Figure 3). E.g., fishers stated “dia bawa rezeki" or "dia bawa ikan kecil' (she/he brings gifts from God or she brings the small fish), and reported that whale sharks cannot be consumed or sold under government and customary regulations. All but one fisher reported positive control beliefs regarding releasing whale sharks, stating that they are "strong", "calm" and "not dangerous" so it's easy to release them (Figure 4). The only reported disadvantage was they sometimes have to cut their net, though other fishers said this wasn’t necessary.

\section{Intentions}

For both wedgefish and hammerheads, there was a disconnect between beliefs and intentions. When fishers were asked if they intend to catch these taxa, answers were inconsistent and neutral on average (for wedgefish, mean score $=4.2 / 7$, for hammerheads, mean score $=3.8 / 7)$. Some fishers stated that they wanted them, others stated that it wasn't their target (Figure 3). Intentions for releasing hammerheads and wedgefish were consistent with beliefs and predominantly negative (Figure 4). For fishers who were neutral $(\mathrm{N}=4)$, they explained that if it was small and alive they would release it, but if it was big and/or already dead then they would not. One fisher stated that if they were protected by the Panglima Laot he would be willing to release them. For whale sharks, reported intentions to catch, avoid and release them were consistent with beliefs; strongly negative for catching them and strongly positive for avoiding and releasing (Figure 3, 4).

\section{Behaviour}

Most fishers reported having caught wedgefish or hammerheads in the past three months, and having not released them, however three fishers reported releasing a small wedgefish and one fisher reported releasing a small hammerhead. No fishers reported catching whale sharks (Figure 3, 4). 


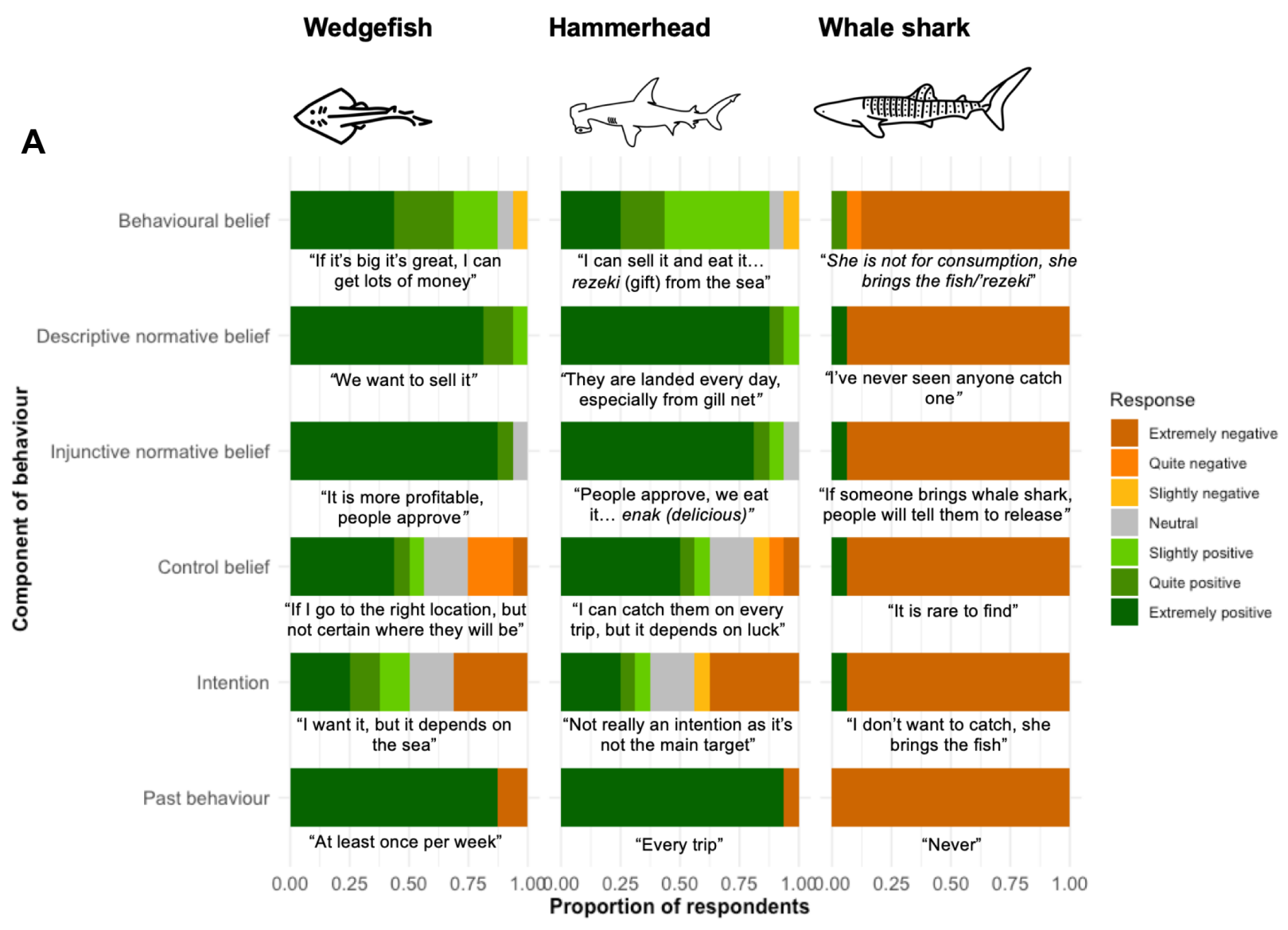

B

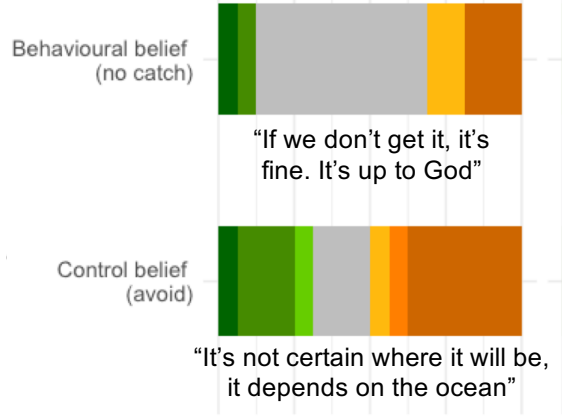

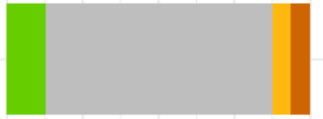

"No problem, it's not the target"

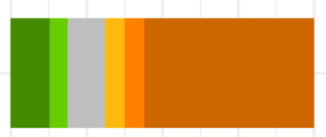

"They are

everywhere"

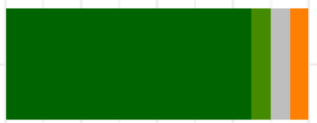

"It's good if we don't catch it, she brings rezeki"

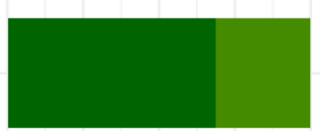

"We can see it, it's big and on the surface"
Response

Extremely negative Quite negative Slightly negative Neutral Slightly positive Quite positive Extremely positive

Proportion of respondents

Figure 3. Summary of the positivity/negativity of fishers' beliefs regarding (A) catching and (B) avoiding wedgefish, hammerheads and whale sharks, where negative pertains to all responses that were 'bad', 'disagree' or 'false', while positive pertains to all responses that were 'good', 'agree' or 'true' (see S1 for details on question framing). The bars represent quantitative results from Likert-scale questions, while the quotes below each bar represent an illustrative qualitative explanation from one or more fisher. 


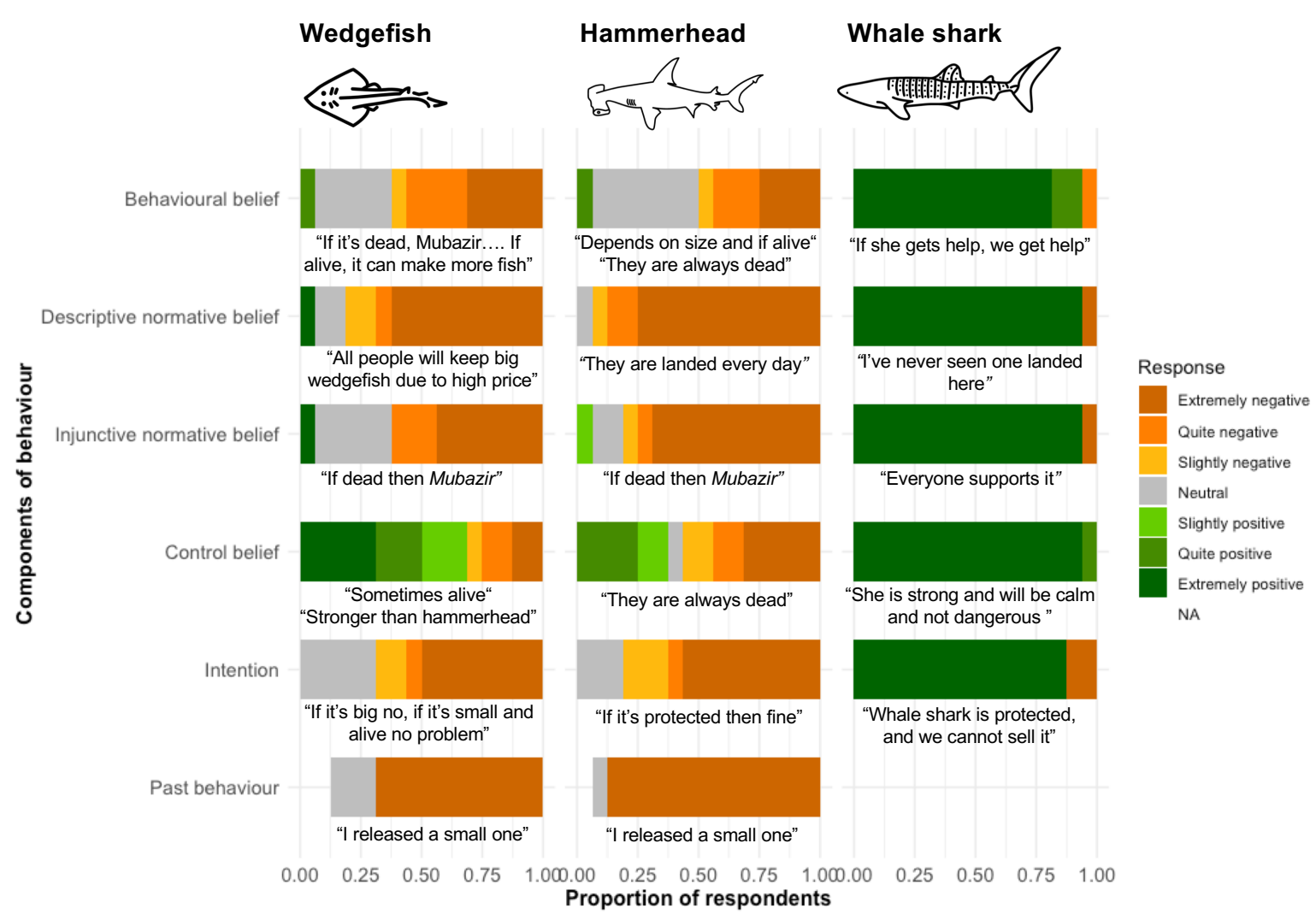

\section{Interpretation of results within the spectrum of bycatch}

Figure 4. Summary of the positivity/negativity fishers' beliefs regarding releasing wedgefish, hammerheads and whale sharks, where negative pertains to all responses that were 'bad', 'disagree' or 'false', while positive pertains to all responses that were 'good', 'agree' or 'true' (see S1 for details on question framing). The bars represent quantitative results from Likert-scale questions, while the quotes below each bar represent an illustrative qualitative explaination from one or more fisher.

These results suggest that in Lhok Rigaih, (by)catch of wedgefish and hammerheads can be diagnosed as valuable secondary catch (Figure 5). In general, fishers believed that (by)catching and retaining hammerhead sharks and wedgefish has advantages for income and subsistence, and widespread social approval. Perceived behavioural control was relativity high, while accounting for intervening factors including the weather, the season and luck or 'God's will'. In contrast, avoiding and releasing hammerheads and wedgefish have disadvantages in terms of lost income, food and 'mubazir', and these behaviours are not widely accepted social norms. Control beliefs regarding avoiding and releasing were mixed, with intervening factors relating to catchability and survivability of hammerheads and shovelnose rays which were generally consistent with independent studies (Ellis et al., 2017; Wosnick et al., 2020). 
On the other hand, catches of whale sharks can be diagnosed as undesirable incidental bycatch (Figure 5), with disadvantages of catching them including no economic value or market, and social disproval because of their perceived role in bringing ' $r e z e k i$. These findings are consistent with what we might expect given the regulatory and economic context of elasmobranch trade in Aceh, Indonesia. It remains legal to catch and domestically-trade hammerhead sharks and wedgefish, both of which have commercial and subsistence value, while whale sharks are legally and customarily protected (Booth, Squires, et al., 2021; Hau et al., 2018; Simeon et al., 2020).

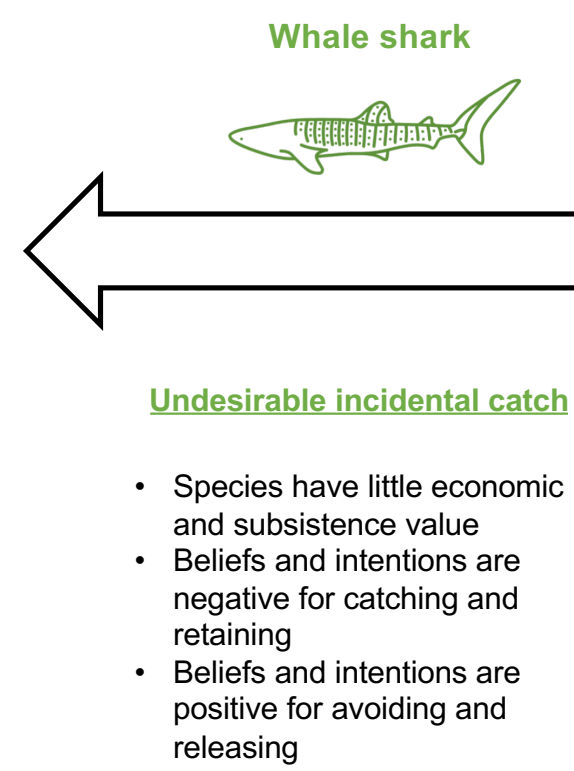

Bycatch mitigation is aligned with interests of fishers.

Hammerheads Wedgefish

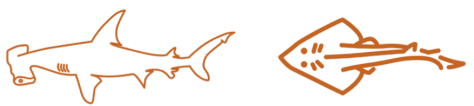

\section{A spectrum of 'bycatch'}

$\underline{\text { Neutral incidental catch }}$

\section{Valuable secondary catch}

- Species have economic and subsistence value

- Beliefs and intentions are positive for catching and retaining

- Beliefs and intentions are negative for avoiding and releasing

Incentives/compensation may be required to align interests of fishers with bycatch mitigation

Figure 5. Results for each study species mapped onto the bycatch spectrum

\section{Implications for behaviour change interventions for bycatch mitigation}

This diagnosis sheds light on potential behaviour change interventions to reduce (by)catch of wedgefish and hammerhead sharks. Firstly, from a technical perspective live-release may be effective for wedgefish due to their relatively higher survivability, while avoidance measures (e.g., spatio-temporal closures) may be more effective for hammerheads. However, in both cases, there is need to change fishers' behavioural and normative beliefs to promote uptake of these behaviours. Since behavioural beliefs for wedgefish and hammerhead sharks were primarily focused on material outcomes - such as money and food - incentives or compensation may be required to re-shape fishers' beliefs regarding the outcomes of bycatch-relevant behaviour. For example, performance-based compensation for live release (Wosnick et al., 2020) or marine 
conservation agreements which 'buy out' fishing rights in spatio-temporal closures (Sykes et al., 2018) could create positive outcome evaluations for bycatch mitigation, since lost income would be compensated for. In parallel, lessons for salient and culturally meaningful conservation messaging can also be drawn from positive behavioural beliefs regarding bycatch mitigation for whale sharks. For example, fishers support live release of whale sharks because they believe whale sharks play an important role in maintaining the health of fish populations (i.e., “dia bawa ikan kecil”). Developing local campaigns for wedgefish and hammerheads using similar messaging - e.g., explaining they are close relatives of whale sharks, and sharing salient messages such as "kami bawa ikan keciljuga" (we also bring the small fish) - could help to re-shape the intrinsic value of wedgefish and hammerheads.

In parallel, positive normative beliefs for bycatch mitigation could be promoted through several avenues. For example, the Panglima Laot plays an important role in establishing legitimate rules and norms for fisher behaviour in Aceh (Quimby, 2015), while religious beliefs (e.g., concepts of rezeki and mubazir) also shape fishers' relationships with marine animals. Therefore, the local Panglima Laot and religious leaders could play important roles as a trusted messengers or block leaders for influencing social norms regarding marine conservation (Abdelzaher et al., 2019; Cinner, 2018; De Lange et al., 2019; Veríssimo et al., 2020). In addition, social recognition for bycatch mitigation such as non-monetary rewards, or local competitions which generate positive peer pressure or group-level incentives, could also help to re-shape normative beliefs (Kotchen \& Segerson, 2020; Nyborg et al., 2016).

More broadly the data also indicate how extrinsic incentives (e.g., food and income) and culture and customary institutions can interact to both help and hinder marine conservation. Since whale sharks bring rezeki and are customarily protected, fishers support pro-conservation behaviour for this species. However, other catches are rezeki, and releasing them is mubazir, so fishers are disinclined to avoid or release them. These intrinsic and normative factors also interact with desires for material well-being. For whale sharks, they are a protected species with "no market" and "not for consumption", therefore social norms and economic expectations act synergistically to drive pro-conservation behaviour. Whereas for wedgefish and hammerheads, intrinsic and extrinsic incentives act synergistically to drive positive beliefs regarding exploitation. These findings also relate to broader behavioural economics literature on interactions between intrinsic and extrinsic incentives, and situations where expectations regarding economic or material 
outcomes can either crowd-in or crowd-out social norms, depending on the context (Cinner et al., 2021; Gneezy et al., 2011; Grillos et al., 2019). In Aceh Jaya, well-designed economic incentives or compensation schemes for bycatch mitigation may help to crowd-in existing social norms for ocean stewardship.

\section{Discussion}

We have presented the Theory of Planned Behaviour (TPB) as a socio-psychological approach for understanding fishers' salient beliefs regarding bycatch and identifying facilitators and barriers to adopting bycatch mitigation practices. We have also illustrated the utility of the TPB via a simple belief elicitation study in a small-scale fishery in Indonesia, to show how it can be applied to gather salient and culturally relevant information that can be used to design behaviour change interventions for bycatch mitigation.

Future applications of the spectrum of bycatch and the TPB could help to advance the use of behavioural sciences in marine research (Andrews et al., 2021), and support the delivery of more effective and sociallyjust marine conservation interventions, which are tailored towards the socio-economic realities of smallscale fisheries (Bennett et al., 2021; Cinner, 2018). For example, as we have illustrated, this approach can help to identify situations where social and economic instruments - such as incentives or trusted messengers - may be needed to encourage uptake of technical fixes for bycatch mitigation (Booth et al., 2019; Cinner, 2018; De Lange et al., 2019). It can also highlight specifically which beliefs or combination or beliefs need to be targeted, to design integrated interventions, for example with a mixture of economic and norms-based solutions which can act synergistically to address multiple barriers and crowd-in pro-conservation behaviour (Booth et al., 2020; Gneezy et al., 2011; Grillos et al., 2019). Our practical experiences during this study also highlighted how using the TPB to ask indirect questions about bycatch-relevant behaviour revealed much richer information than directly asking about motivations regarding catching endangered species. For example, on direct questioning about why fishers catch wedgefish and hammerheads, fishers typically respond with "it's just bycatch", however questions about underlying beliefs reveal the important socio-economic roles of these species in fisher's overall livelihood strategies.

Despite these opportunities, challenges and limitations remain. For example, while the TPB has previously been used to reliably predict other pro/anti-social and environmental behaviour, the relative predictive 
power of the different belief measures within our belief elicitation study remains untested. In the future, TPB surveys of larger samples of fishers across multiple sites, combined with data on real bycatch outcomes from landings surveys, would enable robust statistical modelling to evaluate the predictive potential of the TPB for diagnosing drivers of bycatch, and the relative influence of attitudes, subjective norms and perceived behavioural control on actual fisher behaviour and bycatch performance (e.g., as previously applied to identify determinants of and predict recycling behaviour (Nigbur et al., 2010; Tonglet et al., 2004)). In addition, while the TPB can help to identify intervention points for behaviour change interventions, it cannot necessarily account for complex and unexpected feedbacks that could occur in real interventions (e.g., crowding-in vs. crowding-out) or via dynamic external influences (e.g., fish prices and macro-economic conditions). One option could be to use the belief elicitation study in Aceh Jaya as a baseline, and then conduct a follow-up study in the future following an intervention, to test whether beliefs, intentions and behaviour changed as expected (Dunn et al., 2020).

In summary, we reiterate the need to understand the human dimensions of bycatch, especially in SSFs, for more effective and socially-just marine conservation (Andrews et al., 202 1; Bennett et al., 2021 ; Campbell \& Cornwell, 2008). When endangered marine species form important components of coastal livelihood strategies, technical fixes alone will be insufficient to deliver conservation outcomes. Rather, interdisciplinary approaches are needed to align conservation objectives with positive outcome expectations for fishers

Our bycatch spectrum combined with the TPB could be easily applied for understanding and managing bycatch in other fisheries. This would help to advance the use of behavioural sciences in conservation, and promote action-focused conservation research which moves beyond describing states and mechanisms, towards creating social and behavioural change (Andrews et al., 2021; Balmford et al., 202 1; Williams et al., 2020). Moreover, by focusing on understanding perceptions of fishers, and identifying salient beliefs which drive overexploitation or protection of marine species, the TPB can identify common interests and conflicts of interest between fisheries and conservation objectives, and thus create opportunities to work towards negotiated solutions, which respect the needs and rights of small-scale fishers. As such, wider adoption of socio-psychological approaches could also respond to calls for advancing equity in marine conservation (Bennett et al., 2019, 2021), and we encourage researchers, managers and decision-makers to think more 
holistically about bycatch, and incorporate social and behavioural methods into designing bycatch mitigation interventions in the future.

\section{Acknowledgements}

HB acknowledges the Oxford NaturalMotion Graduate Scholarship from the University of Oxford for funding her DPhil studies. EJMG acknowledges the Pew Charitable Trusts for funding her Pew Marine Fellowship. Field work for this research was supported by a grant from the Save Our Seas Foundation and a Society for Conservation Biology Graduate Student Research Fellowship for HB. All authors would like to thank the fishers, Panglima Laot and local government of Aceh Jaya for their enthusiastic participation in this study. HB is also grateful to Emiel de Lange, who provided early advice and inspiration for this study.

\section{References}

Abdelzaher, D. M., Kotb, A., \& Helfaya, A. (2019). Eco-Islam: Beyond the Principles of Why and What, and Into the Principles of How. Journal of Business Ethics, 155(3), 623-643. https://doi.org/10.1007/s10551-017-3518-2

Ajzen, I. (1991). The theory of planned behavior. Organizational Behavior and Human Decision Processes, 50(2), 179-211. https://doi.org/10.1016/0749-5978(91)90020-T

Ajzen, I. (2011). Behavioral interventions: design and evaluation guided by the theory of planned behavior. In M. M. Mark, S. I. Donaldson, \& B. Campbell (Eds.), Social Psychology and Evaluation (pp. 74-100). Guilford Press.

Ajzen, I. (2013a). Constructing a Theory of Planned Behaviour Questionnaire. Measurement Instrument Database for the Social Science, 1-7. http://www.midss.org/sites/default/files/tpb.construction.pdf

Ajzen, I. (2013b). Sample TPB Questionnaire. Measurement Instrument Database for the Social Science. www.midss.ie

Andrews, E. J., Pittman, J., \& Armitage, D. R. (2021). Fisher behaviour in coastal and marine fisheries. Fish and Fisheries, 22(3), 489-502. https://doi.org/10.1111/faf.12529

Balmford, A., Bradbury, R. B., Bauer, J. M., Broad, S., Burgess, G., Burgman, M., Byerly, H., Clayton, S., Espelosin, D., Ferraro, P. J., Fisher, B., Garnett, E. E., Jones, J. P. G., Marteau, T. M., Otieno, M., 
Polasky, S., Ricketts, T. H., Sandbrook, C., Sullivan-Wiley, K., ... Nielsen, K. S. (2021). Making more effective use of behavioural science in conservation interventions. Biological Conservation, 261(July), 109256. https://doi.org/10.1016/j.biocon.2021.109256

Balmford, A., \& Whitten, T. (2003). Who should pay for tropical conservation, and how could the costs be met? Oryx, 37(2), 238-250. https://doi.org/10.1017/So030605303000413

Bennett, N. J., Cisneros-Montemayor, A. M., Blythe, J., Silver, J. J., Singh, G., Andrews, N., Calò, A., Christie, P., Di Franco, A., Finkbeiner, E. M., Gelcich, S., Guidetti, P., Harper, S., Hotte, N., Kittinger, J. N., Le Billon, P., Lister, J., López de la Lama, R., McKinley, E., ... Sumaila, U. R. (2019). Towards a sustainable and equitable blue economy. In Nature Sustainability (Vol. 2, Issue 11, pp. 991-993). Nature Publishing Group. https://doi.org/10.1038/s41893-019-0404-1

Bennett, N. J., Katz, L., Yadao-evans, W., Ahmadia, G. N., Atkinson, S., Ban, N. C., Dawson, N. M., Vos, A. De, \& Bennett, N. J. (2021). Advancing Social Equity in and Through Marine Conservation. Frontiers in Marine Science, 8(July), 1-13. https://doi.org/10.3389/fmars.2021.711538

Bicchieri, C. (2017). Diagnosing Norms. In C. Bicchieri (Ed.), Norms in the Wild: How to Diagnose, Measure, and Change Social Norms. Oxford Scholarship Online. https://doi.org/10.1093/acprof:oso/9780190622046.001.0001

BMIS. (202 1). Mitigation Techniques. Bycatch Mitigation Information Sytems. https://www.bmisbycatch.org/mitigation-techniques

Booth, H., Chaya, F., Ng, S., Tan, V., Rao, M., Teepol, B., Matthews, E., Lim, A., \& Gumal, M. (2021). Elasmobranch fishing and trade in Sarawak, Malaysia, with implications for management. Aquatic Conservation: Marine and Freshwater Ecosystems, January, 1-16. https://doi.org/10.1002/aqc.3688

Booth, H., Mardhiah, U., Siregar, H., Hunter, J., Giyanto, Putra, M. I. H., Marlow, J., Cahyana, A., Boysandi, Demoor, A. Y. L., Lewis, S., Adhiasto, D., Adrianto, L., \& Yulianto, I. (2020). An integrated approach to tackling wildlife crime: impact and lessons learned from the world's largest targeted manta ray fishery. Conservation Science and Practice, 1-18. https://doi.org/10.1111/csp2.314

Booth, H., Squires, D., \& Milner-Gulland, E. J. (2019). The neglected complexities of shark fisheries, and priorities for holistic risk-based management. Ocean \& Coastal Management, 182(September), 104994. https://doi.org/10.1016/j.ocecoaman.2019.104994

Booth, H., Squires, D., Yulianto, I., Simeon, B., Muhsin, Adrianto, L., \& Milner-Gulland, E. (2021). Estimating economic losses to small-scale fishers from shark conservation : A hedonic price analysis. 
Campbell, L. M., \& Cornwell, M. L. (2008). Human dimensions of bycatch reduction technology: Current assumptions and directions for future research. Endangered Species Research, 5(2-3), 325-334. https://doi.org/10.3354/esro0172

Cinner, J. E. (2018). How behavioral science can help conservation. Science, 362(6417), 889-890. https://doi.org/10.1126/science.aau6028

Cinner, J. E., Barnes, M. L., Gurney, G. G., Lockie, S., \& Rojas, C. (2021). Markets and the crowding out of conservation-relevant behavior. Conservation Biology, 35(3), 816-823. https://doi.org/10.1111/cobi. 13606

Cohen, D., \& Crabtree, B. (2006). Qualitative Research Guidelines Project. Robert Wood Johnson Foundation. http://www.qualres.org/HomeEval-3664.html

Davies, R. W. D., Cripps, S. J., Nickson, A., \& Porter, G. (2009). Defining and estimating global marine fisheries bycatch. Marine Policy, 33(4), 661-672. https://doi.org/10.1016/j.marpol.2009.01.003

Davis, R., Campbell, R., Hildon, Z., Hobbs, L., \& Michie, S. (2015). Theories of behaviour and behaviour change across the social and behavioural sciences: a scoping review. In Health Psychology Review (Vol. 9, Issue 3, pp. 323-344). https://doi.org/10.1080/17437199.2014.941722

De Lange, E., Milner-Gulland, E. J., \& Keane, A. (2019). Improving Environmental Interventions by Understanding Information Flows. Trends in Ecology E Evolution Review, 34(11), 1034. https://doi.org/10.1016/j.tree.2019.06.007

Dent, F., \& Clarke, S. C. (2014). State of the Global Market for Shark Commodities (Vol. 590).

DKP Aceh. (2018). Identifikasi dan inventarisasi calon kawasan konservasi perairan kabupaten Aceh Jaya.

Dulvy, N. K., Simpfendorfer, C. A., Davidson, L. N. K., Fordham, S. V, Bräutigam, A., Sant, G., \& Welch, D. J. (2017). Challenges and Priorities in Shark and Ray Conservation. Current Biology, 27(11), R565R572. https://doi.org/10.1016/j.cub.2017.04.038

Dunn, M. E., Mills, M., \& Veríssimo, D. (2020). Evaluating the impact of the documentary series Blue Planet II on viewers' plastic consumption behaviors. Conservation Science and Practice, 2, e280.

Ellis, J. R., McCully Phillips, S. R., \& Poisson, F. (2017). A review of capture and post-release mortality of elasmobranchs. In Journal of Fish Biology (Vol. 90, Issue 3). https://doi.org/10.1111/jfb.13197

Gneezy, U., Meier, S., \& Rey-Biel, P. (2011). When and Why Incentives (Don't) Work to Modify Behavior. Journal of Economic Perspectives, 25(4), 191-210. https://doi.org/10.1257/jep.25.4.191 
Golden, C. D., Allison, E. H., Cheung, W. W. L., Dey, M. M., Halpern, B. S., McCauley, D. J., Smith, M., Vaitla, B., Zeller, D., \& Myers, S. S. (2016). Nutrition: Fall in fish catch threatens human health. Nature News, 534(7607), 317. https://doi.org/10.1038/534317a

Grillos, T., Bottazzi, P., Crespo, D., Asquith, N., \& Jones, J. P. G. (2019). In-kind conservation payments crowd in environmental values and increase support for government intervention: A randomized trial in Bolivia. Ecological Economics, 166(January), 106404. https://doi.org/10.1016/j.ecolecon.2019.106404

Qanun Aceh Nomor 9 Tahun 2008 tentang Pembinaan Adat dan Adat Istiadat, (2008).

Gupta, T., Booth, H., Arlidge, W., Rao, C., Manoharakrishnan, M., Namboothri, N., Shanker, K., \& MilnerGulland, E. J. (2020). Mitigation of elasmobranch bycatch in trawlers: A case study in Indian fisheries. Frontiers in Marine Science, 7, 571. https://doi.org/10.3389/FMARS.2020.00571

Hall, M. A. (1996). On bycatches. Reviews in Fish Biology and Fisheries, 6(3), 319-352. https://doi.org/10.1007/BFO0122585

Halpern, B. S., Walbridge, S., Selkoe, K. A., Kappel, C. V., Micheli, F., D’Agrosa, C., Bruno, J. F., Casey, K. S., Ebert, C., Fox, H. E., Fujita, R., Heinemann, D., Lenihan, H. S., Madin, E. M. P., Perry, M. T., Selig, E. R., Spalding, M., Steneck, R., \& Watson, R. (2008). A global map of human impact on marine ecosystems. Science, 319(5865), 948-952. https://doi.org/10.1126/science.1149345

Haque, A. B., Cavanagh, R. D., \& Seddon, N. (2021). Evaluating artisanal fishing of globally threatened sharks and rays in the Bay of Bengal, Bangladesh. PLOS ONE, 16(9), e0256146. https://doi.org/10.1371/JOURNAL.PONE.0256146

Harry, A. V., Tobin, A. J., Simpfendorfer, C. A., Welch, D. J., Mapleston, A., White, J., Williams, A. J., \& Stapley, J. (2011). Evaluating catch and mitigating risk in a multispecies, tropical, inshore shark fishery within the Great Barrier Reef World Heritage Area. Marine and Freshwater Research, 62(6), 710. https://doi.org/10.1071/MF 10155

Hau, Y. C. L., Abercrombie, D., Ho, K. Y. K., \& Shea, K. H. S. (2018). King of Shark Fins: A rapid survey on the availability of Shark-like batoid fins in Hong Kong SAR and Guangzhou, China retail markets. http://www.bloomassociation.org/en/wp-content/uploads/2018/12/King-of-shark-fins-not-quitesharks.pdf

IUCN. (2021). IUCN Red List of Threatened Species Version 2021-1. https://www.iucnredlist.org/resources/summary-statistics

Kotchen, M. J., \& Segerson, K. (2020). The Use of Group-Level Approaches to Environmental and Natural 
Resource Policy. Review of Environmental Economics and Policy, 14(2), 173-193. https://doi.org/10.1093/reep/reaaOo2

Lewison, R. L., Crowder, L. B., Read, A. J., \& Freeman, S. A. (2004). Understanding impacts of fisheries bycatch on marine megafauna. 19(11), 598-604.

https://www.sciencedirect.com/science/article/pii/So 169534704002642

Matwal, M., Jothi, P., Joshi, D., Kumar, P., Bloch, F., Sambath, G., Wafer, M. W. M., Choudhury, B. C., \& Kaul, R. (2014). Gujurat's Gentle Giant: Conservation of Whale Shark (Rhincodon typus) in Gujarat.

Newing, H., Eagle, C. M., Puri, R. K., \& Watson, C. W. (2010). Conducting research in conservation: Social science methods and practice. In Conducting Research in Conservation: Social Science Methods and Practice. Routledge. https://doi.org/10.4324/9780203846452

Nigbur, D., Lyons, E., \& Uzzell, D. (2010). Attitudes, norms, identity and environmental behaviour: Using an expanded theory of planned behaviour to predict participation in a kerbside recycling programme. British Journal of Social Psychology, 49(2), 259-284. https://doi.org/10.1348/014466609X449395

Nyborg, K., Anderies, J. M., Dannenberg, A., Lindahl, T., Schill, C., Schlüter, M., Adger, W. N., Arrow, K. J., Barrett, S., Carpenter, S., Chapin, F. S., Crépin, A. S., Daily, G., Ehrlich, P., Folke, C., Jager, W., Kautsky, N., Levin, S. A., Madsen, O. J., ... De Zeeuw, A. (2016). Social norms as solutions. Science, 354(6308), 42-43. https://doi.org/10.1126/science.aaf8317

Oyanedel, R., Gelcich, S., \& Milner-Gulland, E. J. (2020). Motivations for (non-)compliance with conservation rules by small-scale resource users. Conservation Letters, 15(5), e12725. https://doi.org/10.1111/conl.12725

Quimby, B. (2015). Emerging customs: Small-scale fishing practices in Aceh, Indonesia. Applied Geography, 59, 125-130. https://doi.org/10.1016/j.apgeog.2014.11.026

RStudio Team. (2020). RStudio: Integrated Development for R. RStudio, PBC. http://www.rstudio.com/.

Selig, E. R., Hole, D. G., Allison, E. H., Arkema, K. K., McKinnon, M. C., Chu, J., de Sherbinin, A., Fisher, B., Glew, L., Holland, M. B., Ingram, J. C., Rao, N. S., Russell, R. B., Srebotnjak, T., Teh, L. C. L., Troëng, S., Turner, W. R., \& Zvoleff, A. (2018). Mapping global human dependence on marine ecosystems. Conservation Letters, e12617. https://doi.org/10.1111/conl.12617

Selig, E. R., Turner, W. R., Troëng, S., Wallace, B. P., \& Halpern, B. S. (2014). Global Priorities for Marine Biodiversity Conservation. PLoS ONE, 9(1), 82898. https://doi.org/10.1371/journal.pone.0082898 Shester, G. G., \& Micheli, F. (2011). Conservation challenges for small-scale fisheries: Bycatch and habitat 
impacts of traps and gillnets. Biological Conservation, 144(5), 1673-1681.

https://doi.org/10.1016/j.biocon.2011.02.023

Simeon, B. M., Fajri, I., Ula, S., Muttaqin, E., Ichsan, M., Dharmadi, \& Damora, A. (2020). Laporan teknis pemantauan hasil tangkapan hiu dan pari di Provinsi Aceh(Issue December).

St John, F. A. V., Edwards-Jones, G. A., \& Jones, J. P. (2010). Conservation and human behaviour: Lessons from social psychology. Wildlife Research, 37, 658-667. https://doi.org/10.1071/WR 10032

Stern, M. J. (2018). Social science theory for environmental sustainability: a practical guide. Oxford University Press.

Stevenson, T. C., Tissot, B. N., \& Walsh, W. J. (2013). Socioeconomic consequences of fishing displacement from marine protected areas in Hawaii. Biological Conservation, 160, 50-58. https://doi.org/10.1016/j.biocon.2012.11.031

Sykes, H., Mangubhai, S., \& Manley, M. (2018). Contribution of Marine Conservation Agreements to Biodiversity Protection, Fisheries Management and Sustainable Financing in Fiji. https://fiji.wcs.org/Portals/82/reports/WCS MCA Fiji Report 040518 2.pdf?ver=2018-05-08231334-113

Tonglet, M., Phillips, P. S., \& Read, A. D. (2004). Using the Theory of Planned Behaviour to investigate the determinants of recycling behaviour: A case study from Brixworth, UK. Resources, Conservation and Recycling, 41(3), 191-214. https://doi.org/10.1016/j.resconrec.2003.11.001

Veríssimo, D., Vieira, S., Domingas Monteiro, |, Hancock, J., \& Nuno, A. (2020). Audience research as a cornerstone of demand management interventions for illegal wildlife products: Demarketing sea turtle meat and eggs. Conservation Science and Practice, 2(3), e 164. https://doi.org/10.1111/CSP2.164

Williams, D. R., Balmford, A., \& Wilcove, D. S. (2020). The past and future role of conservation science in saving biodiversity. Conservation Letters, 13(4), 1-7. https://doi.org/10.1111/conl.12720

Wilson, C., \& Linkie, M. (2012). The Panglima Laot of Aceh: a case study in large-scale community-based marine management after the 2004 Indian Ocean tsunami. Oryx, 46(4), 495-500. https://doi.org/10.1017/So030605312000191

Wosnick, N., Da Costa De Lima Wosiak, C., \& Machado Filho, O. C. (2020). Pay to conserve: what we have achieved in 10 years of compensatory releases of threatened with extinction guitarfishes. Animal Conservation, 1-3. https://doi.org/10.1111/acv.12651

Yulianto, E. S., Lestari, W. P., \& Jayanti, D. (2018). Laporan Survei Sosial Ekonomi Kawasan Konservasi 
